Vol. 3, No. 01; 2020

ISSN: 2581-4664

\title{
THE EFFECT OF COMMUNICATION, EDUCATION, AND TRUST ON MEMBER PERFORMANCE AND ITS IMPLICATIONS ON THE ORGANIZATIONAL PERFORMANCE :STUDY IN PIDIE POLANTAS
}

\author{
Rina Bintar Handayani, Mukhlis and Said Musnadi \\ Department of Management, Universitas Syiah Kuala, Indonesia \\ http://doi.org/10.35409/IJBMER.2020.3153
}

\begin{abstract}
This study is to analyze / test the effect of communication, education, and trust on member performance and its implications on the organizational performance. The object is Pidie Polantas Organization, while the variables are communication, education, trust, member performance and organizational performance. The population is all personnel, both the Police and Civil Servants, totaling 148 personnels. Sample is taken using census method, so the amount of population is the same with the amount of the sample. Structural Equation Modeling is used for analyzing the data, with AMOS application. The research result shows that communication effects member performance, Education effects member performance, Trust effects member performance, Member performance effects organizational performance, Communication effects organizational performance, Education effects organizational performance, Trust effects organizational performance, Communication effects organizational performance through member performance, Education effects organizational performance through member performance, and Trust effects organizational performance through member performance. This research model can be a reference for academic and practical lessons that update the previous theories especially in the causalities. The new findings lies in its new object, that is the Pidie Polantas, and the combination of causality theories. The limitation resides in the amount of variables, and only use one object.
\end{abstract}

Keyword: Communication, Education, Trust, Member Performance and Organizational Performance.

\section{INTRODUCTION}

The Police Regiment has the main task of carrying out duty of the Indonesia National Police in the district / city area. One of the police unit in the Resort Police is the Traffic Police Unit, that is called Polantas. The task of Polantas is to carry out the Police task in the field of Traffic which includes all businesses, work and activities in Traffic control to prevent and eliminate all forms of disturbances and threats in order to guarantee security, order, safety and smooth traffic on public roads.

One of the main problems in the organization of Polantas in Pidie district, Indonesia, is the poor performance of members, especially in reducing the level of traffic accidents in the 


\section{International Journal of Business Management and Economic Review}

Vol. 3, No. 01; 2020

ISSN: 2581-4664

Pidie Regional Police jurisdiction, where in recent years the number of traffic accidents were still relatively high and continued to show an increase from year to year. This certainly is an indication that the performance of members of the PidiePolantas in carrying out their duties has not been maximized, especially in providing protection, security and outreach in good traffic and mutual respect with fellow road users. Indications of an increase in traffic accidents are caused by many factors, for example many people who do not have a driving license (SIM), do not comply with traffic signs and the condition of vehicles that are not roadworthy that triggers traffic accidents.

From the observations, many violations and traffic accidents wasoccured due to careless attitudes of road users, road conditions, and vehicle conditions. Various violations of red lights on traffic lights (traffic light), motorists did not wear helmets, did not have a SIM (Driving License), forgot not to bring a SIM or vehicle registration, often happened.

Actually, legal awareness is needed for motorcyclists and other modes of transportation. Legal awareness is self-control in driving. Drivers who have full legal awareness and have good and safe driving procedures will always be compelled to obey the existing traffic rules. Drivers who have full legal awareness in driving certainly will not be careless who can endanger the safety of themselves or others.

The low performance of members of the Pidie Polantas can be seen from the still low awareness of the public on the importance of good and responsible traffic, such as obeying all traffic rules, respecting fellow road users and respecting any applicable provisions in traffic. The low level of public awareness can be seen from the high level of traffic accidents that continue to increase each year. This will certainly have an impact on the performance of the Pidie Polantas organization in providing counseling and protection as well as protection to the community, especially road users in the Pidie Regional Police Legal Area.

The phenomenon is related to the low performance of members, one of which is caused by leadership factors that have not been fully able to increase motivation and organize all potential resources to achieve organizational goals. The results of research conducted by (Atmojo, 2012) stated that leadership has an influence in improving employee performance in an organization. The phenomenon of the member performance can be seen from the reduction of community satisfaction, as well as the ability of members to handle various cases that were occured. Performance in the middle level of organization can be seen from the solidity in the organizational structure and good organizational management, thus allowing members to work according to their duties and functions.And, performance inthe lower level can be seen in the increasing quality of service to the community. In meeting the needs of community services, the members workand provide several product/services, that are making a Driving License, conducting school security (PKS) scouting then as well as lighting, counseling, reporting through mass media, films and brochures.

Whereas performance indicators are related to the targeted results and realization that can be achieved by members. Meanwhile performance indicators are used for activities that can only be determined more qualitatively on the basis of observable behavior. Performance indicators also suggest a prospective point of view (forward looking) rather than retrospectively (looking back). This shows the way to the performance aspects that need to be observed. While the training program in order to improve the performance of members also has not been able to run as expected, because the training program is only attended by certain members and does not 


\section{International Journal of Business Management and Economic Review}

Vol. 3, No. 01; 2020

ISSN: 2581-4664

involve all members, so that the achievement of member performance is hampered. The low performance of members of the Pidie Polantas is caused by several factors, but in this study the authors limit it to only three variables namely communication, education and trust.

Lack of communication carried out by members in providing counseling to the community can provide in improving member performance. Communication patterns are forms or patterns of relationships between two or more people in the process of linking two components, namely a picture or plan that becomes steps in an activity with components that are an important part of the relationship between organizations or people. In this study, communication patterns are ways, work systems, forms, and structures that are used to communicate (convey knowledge / information / messages).

While the education problems of police officers can also have an impact on the performance of members and organizational performance, meaning that the higher the level of education owned by members, the members who have an adequate level of education will have adequate knowledge, so that members of the Pidie Polantas can carry out the main duties of the traffic police well, so as to increase community satisfaction, especially the people in the jurisdiction of the Pidie Police Station.

\section{LITERATURE REVIEW \\ Organizational Performance}

Organizational performance is an indicator of the level of achievement that can be achieved and reflects the success of an organization, and is the result achieved from the behavior of organizational members. Performance can also be said as a result (output) of a particular process carried out by all components of the organization against certain sources used (input). Furthermore, performance is also the result of a series of process activities carried out to achieve certain organizational goals. For an organization, performance is the result of collaborative activities among members or components of the organization in order to realize organizational goals.

The organization is a structure of the division of labor and structure of work relations between groups of people holding positions that work in a certain way to jointly achieve certain goals. According to (Atmosudirdjo, 1982), the organization is the structure of the division of labor and the structure of the working relationship between a group of people holding positions that work together to achieve certain objectives.

Organization is any form of alliance between two or more people who work together and are formally bound in the context of achieving a goal that has been determined in the bond where there is a person, some people called superiors and a person / group called subordinates (Atmosudirdjo, 1982)

An organization is a group of people (two or more) who are formally united in a partnership to achieve the stated goals. An organization is formed because it has the basis and objectives to be achieved. According to (Mooney and Reiley, 1931), organization is a form of human union to achieve a common goal. But we need to understand that the basis of the organization, not "who" but "what" means that what matters is not who is the person who will hold the organization, but the "what" is the task of the organization.

An organization can be formed because it is influenced by several aspects such as the unification of vision and mission and the same goals as the realization of the existence of a group 


\section{International Journal of Business Management and Economic Review}

Vol. 3, No. 01; 2020

ISSN: 2581-4664

of people to the community. Organizations that are considered good are organizations that can be recognized by the surrounding community, because they contribute such as taking human resources in the community as members so as to reduce unemployment.

"Organizational performance is the totality of the work achieved by an organization achieving the goals of the organization means that, the performance of an organization can be seen from the degree to which the organization can achieve goals based on the goals set previously". (Sujardi, 2009). According to (Sobandi et al., 2006) Organizational performance is something that has been achieved by the organization within a certain period of time, both related to inputs, outputs, outcomes, benefits, and impacts.

\section{Employee Performance}

According to (Margiati, 1999), the concept of performance is an abbreviation of work energy kinetics which in English is performance. Performance is the output produced by functions or individuals on a particular job or profession. Performance that is often also referred to as work performance is the result of work in terms of quantity and quality achieved by a person in carrying out tasks according to the responsibilities given at a certain time. (Hariandja and Hardiwati, 2002) defined individual performance as individual work performance that is set based on standards or criteria set by an organization.

Based on the above understanding, it can be concluded that performance or often referred to as work performance or job performance is the quality and quantity of an individual's work output in a particular activity and according to the measurements that apply to the work in question. This measure is determined by the organization determined as a target in one period.

In this research, the mention of "employee performance" is likened to the "member performance", considering that the said "member" is more frequently used in the organization of PidiePolantas. The performance of members of the PidiePolantas is the performance achievements produced by members both individually and in organizational membership, based on the main tasks and functions of each member in the PidiePolantas Organization. The qualityof the performance especially lies in providing excellent service to the community for the sake of the realization of security and order in the community.

Based on the above understanding, the Police which are an integral part of the culture of the community must build partnerships with the community means having a police perspective that is not only emphasized on traditional law enforcement. This broader view is recognized as providing value to activities that help create order and the well-being of a community (community).

Meanwhile according to (Bernardin, 2009) there are six criteria in work including:

(1) Quality of work, where the results of activities carried out near perfect in the sense of adjusting some of the ideal ways of performing activities or meeting the expected goals in an activity. Quality of work is measured by employee perceptions of the quality of work produced and the perfection of the task of the skills and employee ability;

(2) Quantity, which is the amount produced, expressed in terms such as the number of units, the number of activity cycles completed by employees, and the number of activities produced;

(3) Timeliness, the level of an activity completed at the beginning of the desired time from the point of view of coordination with the outputs and maximizing the time available for other activities. Timeliness is measured by the employee's perception of an activity that is 


\section{International Journal of Business Management and Economic Review}

Vol. 3, No. 01; 2020

ISSN: 2581-4664

completed at the beginning of time until it becomes output;

(4) Effectiveness, level of use of Organizational Resources (energy, money, technology, raw materials) are maximized with the aim of increasing the profit of each unit in the use of resources, work effectiveness, employee perceptions in carrying out tasks, effectiveness of completing tasks specified by the organization;

(5) Independence, is the level at which an employee can perform his work function without asking for help, guidance from the supervisor, or the involvement of the supervisor interfering in the work of the employee to avoid adverse results. Independence will be measured from the employee's perception of the task in carrying out the work functions of each employee in accordance with the responsibilities of the employee itself;

(6) Work Commitments; is the level where employees have a commitment to work with the organization and employee responsibilities to the organization. Measurement using employee perceptions in fostering relationships with the organization and responsibilities, loyalty to the organization.

\section{Communication}

Communication is a process of delivering information (messages, ideas, ideas) from one party to another party. In general, communication is done verbally or verbally which can be understood by both parties. if there is no verbal language that can be understood by both, communication can still be done using gestures, showing certain attitudes, such as smiling, shaking his head, shrugging his shoulders. This way is called nonverbal communication.Communication is an effort to encourage others to interpret opinions as what is desired by the person who has the income. Communication is a way to convey ideas, facts of mind, feelings and values to others. The implementation always involves two parties, the sender (communicator) and the recipient (communicant).

According to (Effendy, 2013), if two people are involved in communication, for example in the form of a conversation, then communication will occur or last as long as there is a common meaning about what is said. The similarity of language used in the conversation does not necessarily lead to the same meaning. In other words, understanding the language alone does not necessarily understand the meaning that is conveyed by the language.Meanwhile, according to (Handoko, 2008), communication is the process of transferring understanding in the form of ideas or information from one person to another. The transfer of understanding involves more than just words used in conversation, but also facial expressions, intonation, vocal drop points and so on. And effective transfer requires not only the transmission of data, but that someone transmits news and receives it highly depends on certain skills (reading, writing, listening, speaking etc.) to make the process of exchanging information.

Communication can be defined as the delivery of information between two or more people. Communication is a vital process in an organization because communication is needed to achieve effectiveness in leadership, planning, control, coordination, training, conflict management and other organizational processes.(Ghani, 2001) explained that in an Islamic perspective, communication in addition to creating a vertical relationship to God, also to establish horizontal communication with fellow human beings. Communication with God is reflected through fardu worship (prayers, fasting, alms and hajj) which aims to form piety. Whereas communication with fellow human beings is manifested through the suppression of 


\section{International Journal of Business Management and Economic Review}

Vol. 3, No. 01; 2020

ISSN: 2581-4664

social relations called muamalah which is reflected in all aspects of human life such as social, cultural, political, economic, artistic and so on.

\section{Education}

Education is a word that we are very familiar with in our daily lives, because education is an important activity carried out by almost all members of society. Education as something important is inseparable from the many opinions and assumptions about the true meaning and definition of education. In this article I intend to write the opinions of experts about education which is certainly different depending on their respective perceptions. This article will certainly open our minds about how to respond to education.

According to (Hasibuan, 2011), education is an eternal process of higher adjustment for beings who have developed physically and mentally that are free and aware of God as manifested in the natural, intellectual, emotional and will of humans. Meanwhile, according to Rivai, (Zainal, 2015), education is a process of experience. Because life is growth, education means helping inner growth without being limited by age. The process of growth is the process of adjusting to each phase and adding skills in one's development. While the notion of education according to (Widjaja, 2003) education is a conscious and planned effort to create an atmosphere of learning and learning process so that students actively develop their potential to have spiritual spiritual strength, self-control, personality, intelligence, noble character, and skills that are needed himself and the community.

The educational method in the strict sense is to increase the expertise and skills of managers in effectively leading subordinates. Education is a means of increasing skills and expertise for employees or employees. Education is an activity to improve one's work ability in relation to economic activities. Education helps employees understand a practical knowledge and its application in order to improve the skills, abilities and attitudes needed by the organization in achieving its goals.

(Simamora, 2004) explains that "Education (education) is a systematic process of changing employee behavior in a direction in order to improve organizational goals. In education an environment is created where employees can acquire or learn specific attitudes, abilities, expertise, knowledge and behavior related to work. Education usually focuses on providing employees with specific skills or helping them correct weaknesses in their performance. In education given instructions to develop skills that can be directly used at work. Through education, every effort is made in order to improve the performance of employees at the current occupation ".

Based on the above meanings, it concludes that education is an activity to improve the ability and improve employee performance in carrying out their duties by increasing specific skills, knowledge, skills, attitudes and behaviors related to their work.

\section{Trust}

According to (Lussier, 2016) Trust is a positive hope that will not be received by others. Trust is not given away, this is obtained by positive expectations, based on knowledge, familiarity, and experience with others, takes time to develop.The three types of trust in different organizational human relations, knowledge, and trust are based on identification. They can also be called trust levels, because they form a building block of trust. Organizational trust is based 


\section{International Journal of Business Management and Economic Review}

Vol. 3, No. 01; 2020

ISSN: 2581-4664

on this assumption. Two people enter a new relationship without prior experience, they are not sure about each other, they believe that they are vulnerable if they express too much too quickly, and they are not sure how long the relationship will last.

According to (Robbins and Judge, 2012) trust is something that is expected from honesty and cooperative behavior based on sharing the same norms and values. Trust is a positive hope that others will not deceive and disappoint you. Thus it can be explained that trust is the degree to which a person who believes puts a positive attitude towards the goodwill and reliability of others who are trusted in changing and risky situations. Trust (trust) is a belief in the integrity, ability, character of someone or something. In organizing trust is important because it will help manage complexity, develop action capacity, enhance collaboration and enhance organizational learning. Trust in superiors is an important element that influences the emergence of commitment to employees.

\section{Previous Research Review}

Research conducted by (Fahmi, 2013) where that took place at the Bank Syariah Mandiri Banda Aceh Branch, communication has an influence in improving employee performance.

Research conducted by (Sulaiman, 2013) proved that to improve employee performance and the performance of the Aceh Jaya District Secretariat, it is necessary to consider factors that influence employee performance and the performance of the Aceh Jaya District Secretariat such as trust.

Then research (Jamaluddin, 2014) proved that education has an influence on improving employee performance at the Ujung Batee Aceh Besar Brackish Water Aquaculture Center.

\section{Research Hypothesis}

From the discussion above, the authors formulate the research hypothesis as follows.

$\mathrm{H} 1$ : communication effects member performance,

$\mathrm{H} 2$ : Education effects member performance,

H3 : Trust effects member performance,

H4 : Member performance effects organizational performance,

H5 : Communication effects organizational performance,

H6 : Education effects organizational performance,

H7 : Trust effects organizational performance,

H8 : Communication effects organizational performance through member performance,

H9 : Education effects organizational performance through member performance, and $\mathrm{T}$

$\mathrm{H} 10$ : rust effects organizational performance through member performance.

\section{RESEARCH METHOD}

\section{Location and Research Object}

This research is conducted at the Pidie Polantas Organization, while the variables are communication, education, trust, member performance and organizational performance. The population is all personnel, both the Police and Civil Servants, totaling 148 personnels. Sample is taken using census method, so the amount of population is the same with the amount of the sample. 
Vol. 3, No. 01; 2020

ISSN: 2581-4664

\section{Data Analysis Tools}

After collecting data, the next step is to analyze the data using SEM (Structual Equation Modeling) with the AMOS (Analysis of Moment Structure) application. The use of SEM allows researchers to examine the relationships between complex variables to get an overall picture of the whole model.

According to (F. Hair Jr et al., 2014) SEM method is a development of path analysis and multiple regression which are both a form of multivariate analysis.By analyzing all the questions on the independent variables so that the hypothesis test results are obtained. If the results of the hypothesis test do not meet the eligibility index requirements, then it needs to be analyzed by the confirmatory factor analysis (CFA) method.

\section{RESULT}

\section{Characteristics of Respondents}

Respondent characteristicin this study consists of gender, age level of respondents, marital status, and the last education. Based on the result, the authors then identified the characteristics of the respondents as shown in the following.

\section{Table 1. Respondent Characteristics}

\begin{tabular}{|c|c|c|c|}
\hline No. & Description & Frequency & Percent \\
\hline 1. & $\begin{array}{l}\text { Gender : } \\
\text { - Men } \\
\text { - } \quad \text { Women } \\
\end{array}$ & $\begin{array}{l}94 \\
54 \\
\end{array}$ & $\begin{array}{l}63.5 \\
36.5 \\
\end{array}$ \\
\hline 2. & $\begin{array}{l}\text { Age of respondent: } \\
\text { - } \quad<20 \text { years old } \\
\text { - } 21-30 \text { years old } \\
\text { - } \quad 31-40 \text { years old } \\
\text { - } 41-50 \text { years old } \\
\text { - } \quad>50 \text { years old }\end{array}$ & $\begin{array}{l}0 \\
4 \\
46 \\
67 \\
31\end{array}$ & $\begin{array}{l}0.0 \\
2.7 \\
31.1 \\
45.3 \\
20.9\end{array}$ \\
\hline 3. & $\begin{array}{l}\text { Marital status } \\
\text { - } \quad \text { Not Married } \\
\text { - } \quad \text { Married } \\
\text { - } \quad \text { Widowed/Widow } \\
\end{array}$ & $\begin{array}{l}51 \\
91 \\
6 \\
\end{array}$ & $\begin{array}{l}34.5 \\
61.5 \\
4.1\end{array}$ \\
\hline 4. & \begin{tabular}{ll}
\multicolumn{2}{l}{ Education } \\
- $\quad$ High school \\
- $\quad$ Military Academy \\
- $\quad$ Bachelor \\
- $\quad$ Postgraduate \\
\end{tabular} & $\begin{array}{l}28 \\
35 \\
72 \\
13\end{array}$ & $\begin{array}{l}18.9 \\
23.6 \\
48.6 \\
8.8\end{array}$ \\
\hline 5. & $\begin{array}{l}\text { Income } \\
\text { - } \quad \text { Rp. } 2,500,000-2,999,999 \\
\text { - } \quad \text { Rp. 3,000,000-3,499,999 } \\
\text { - } \quad \text { Rp. 3,500,000-3,999,999 } \\
\end{array}$ & $\begin{array}{l}10 \\
42 \\
53 \\
\end{array}$ & $\begin{array}{l}6.8 \\
28.4 \\
35.8 \\
\end{array}$ \\
\hline
\end{tabular}




\section{International Journal of Business Management and Economic Review}

Vol. 3, No. 01; 2020

ISSN: 2581-4664

\begin{tabular}{|l|l|l|l|l|}
\hline \hline & Rp. 4,000,000-4,499,999 & 34 & 23.0 \\
- >Rp. 4,500,000 & 9 & 6.1 \\
\hline Sum & 148 & 100.0 \\
\hline
\end{tabular}

Source: Primary Data, 2019 (processed)

The rable 1 it explains that as many as 94 people or $63.5 \%$ consist of male respondents and as many as 54 people or $36.5 \%$ consist of female respondents, thus respondent member in the PidiePolantasis dominated by male respondents.

Based on the age of respondents it figures that as many as 4 people or $2.7 \%$ aged between 21 to 30 years, as many as 46 people or $31.1 \%$ of respondents aged 31 to 40 years, as many as 46 people or $31.1 \%$, respondents aged $41-50$ years and as many as 67 people or $45.3 \%$ of respondents aged $41-50$ years and as many as 31 people or $20.9 \%$ aged more than 50 years. Thus respondents with an age level of 31-40 years are more dominant than respondents aged 21-30 years.

Characteristics of respondents based on marital status reveals that as many as 51 people or $34.5 \%$ of respondents are single, 91 people or $61.5 \%$ of respondents have married and as many as 6 people or $4.1 \%$ are widowed / widowed. Thus it explains that respondents who are married are more dominant than respondents who are not married.

Then the characteristics of the next respondent is regarding the education level of the respondent, that figures as many as 28 people or $18.9 \%$ have graduated their high school education, 35 people or $23.6 \%$ of respondents have graduated the Military Academy, 72 people or $48.6 \%$ have graduated the Bachelor degree while the last postgraduate educated respondents are 13 people or $8.8 \%$ of the total respondents studied.

Regarding monthly income, it concludes that the respondentawho have income of Rp. 2,500,000 $2,999,999$, -, as many as 10 people or $6.8 \%$,respondents have income of Rp. 3,000,000 $3,499,999$, - as many as 42 people or $28.4 \%$, respondents who have income of Rp. 3,500,000 $3,999,999$, - as many as 53 people or $35.8 \%$, respondents who have income of Rp. 4,500,000 $4,499,999$, - as many as 34 people or $23.0 \%$, and the respondents who have income of more than Rp. 4,500,000 as many as 9 people or $6.1 \%$ of the total respondents.

Based on table 1 above it figures that the PidiePolantas is dominated by male members with an average age level of 31-40 years which is the productive age level for a member in achieving the performance expected by the organization, then it can also be seen that in the average the members have married so they have clearer responsibilities, with an average level of education being a bachelor with an income level of Rp. 3,500,000 - 3,999,999, -, - monthly. this is in accordance with their duties and responsibilities in improving community order and community services in the Pidie Regency. However, in this study, researchers do not distinguish the analysis between gender, marital status, age and income.

\section{Confirmatory Factor Analysis for Normality Test}

The latent variables of knowledge sharing and knowledge management system in this confirmatory model consist of 24 indicators as forming indicators. The results of data processing for confirmatory factor analysis for all constructs in this study are shown in Figure below. 
Vol. 3, No. 01; 2020

ISSN: 2581-4664

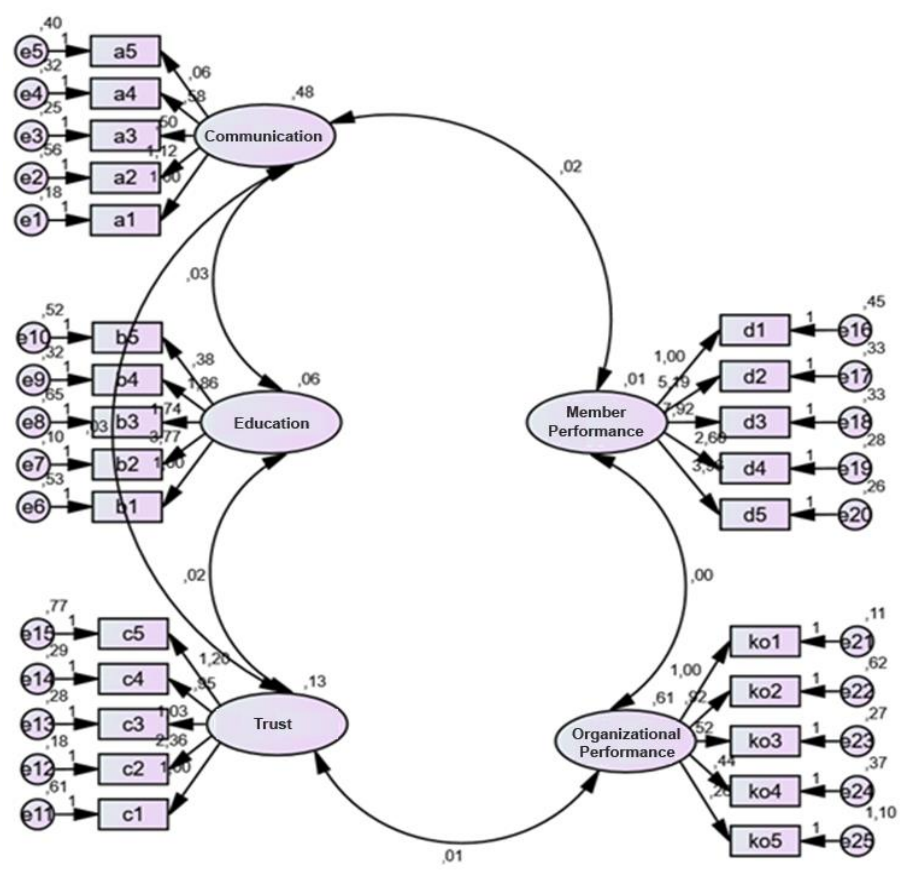

Figure 1. Constructive Confirmatory Factor Analysis

The loading factor that represents the contribution of each indicator to its variable can be seen in the following Table 2 .

Table 2. Loading Factor Indicators For Variables

\begin{tabular}{|lll|l|}
\hline Code & Direction & Indicator & Estimate \\
\hline a1 & $<---$ & Communication & 0.850 \\
a2 & $<---$ & Communication & 0.716 \\
a3 & $<---$ & Communication & 0.574 \\
a4 & $<---$ & Communication & 0.577 \\
a5 & $<---$ & Communication & 0.569 \\
b1 & $<---$ & Education & 0.598 \\
b2 & $<---$ & Education & 0.992 \\
b3 & $<---$ & Education & 0.540 \\
b4 & $<---$ & Education & 0.600 \\
b5 & $<---$ & Education & 0.534 \\
c1 & $<---$ & Trust & 0.503 \\
c2 & $<---$ & Trust & 0.905 \\
c3 & $<---$ & Trust & 0.558 \\
c4 & $<---$ & Trust & 0.536 \\
c5 & $<---$ & Trust & 0.637 \\
\hline
\end{tabular}




\section{International Journal of Business Management and Economic Review}

Vol. 3, No. 01; 2020

ISSN: 2581-4664

\begin{tabular}{|lll|l|}
\hline \hline Code & Direction & Indicator & Estimate \\
\hline d1 & $<---$ & Member Performance & 0.773 \\
d2 & $<---$ & Member Performance & 0.749 \\
d3 & $<---$ & Member Performance & 0.816 \\
d4 & $<---$ & Member Performance & 0.506 \\
d5 & $<---$ & Member Performance & 0.632 \\
ko1 & $<---$ & Organizational Performance & 0.920 \\
ko2 & $<---$ & Organizational Performance & 0.673 \\
ko3 & $<---$ & Organizational Performance & 0.619 \\
ko4 & $<---$ & Organizational Performance & 0.586 \\
ko5 & $<---$ & Organizational Performance & 0.687 \\
\hline
\end{tabular}

Source: Primary Data, 2019 (processed)

Based on table 2 above, it can be seen that all indicators included in the model have fulfilled the requirements to be included in the subsequent data processing. Before proceeding to the structural stage, the feasibility of the existing model will be seen first, this is because there is no single indicator that has a value of less than 0.5 . Testing the feasibility of the model is done by testing the model fit through goodness of fit.

\section{Structural Equation Modeling Analysis (SEM)}

The next analysis is the full model of Structural Equation Model (SEM) analysis, after an analysis of the uni dimensionality level of the indicators forming latent variables has been tested with confirmatory factor analysis. The result of data processing through the full SEM model stage is obtained by conducting a suitability test and a statistical test. The result the SEM full model analysis is shown in Figure 2.

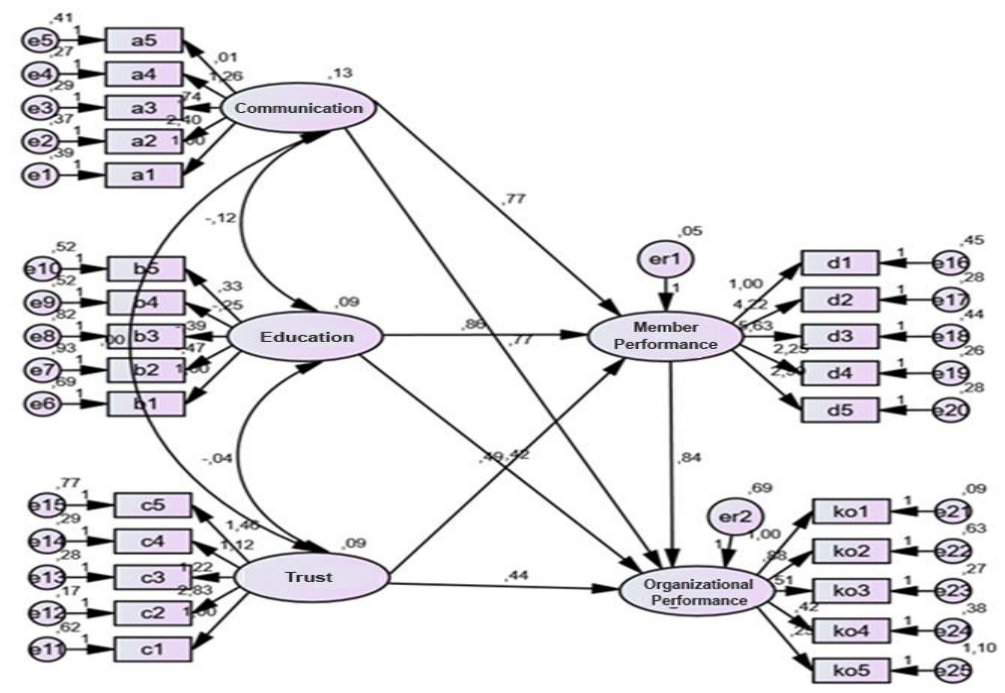

Figure 2. Structural Equation Model (SEM) Test Results 
Vol. 3, No. 01; 2020

ISSN: 2581-4664

\section{Hypothesis Test}

Direct Effect

After all assumptions is fulfilled, then hypothesis testing will be carried out as the analysis in the previous chapter. Critical Ratio (CR) and P Value are the determinants.

Table 3. Standardized Regression Weights

\begin{tabular}{|c|c|c|c|c|c|}
\hline & & Estimate & S.E. & C.R. & $\mathrm{P}$ \\
\hline Member Performance & <--- Communication & 0.776 & 0.080 & 9.733 & **** \\
\hline Member Performance & $<---$ Education & 0.861 & 0.108 & 7.951 & $* * *$ \\
\hline Member Performance & $<---$ Trust & 0.492 & 0.067 & 7.367 & $* * *$ \\
\hline $\begin{array}{l}\text { Organizational } \\
\text { Performance }\end{array}$ & $\begin{array}{ll}<--- & \text { Member } \\
\text { Performance }\end{array}$ & 0.845 & 0.103 & 8.235 & *** \\
\hline $\begin{array}{l}\text { Organizational } \\
\text { Performance }\end{array}$ & $<---$ Communication & 0.777 & 0.089 & 8.763 & $* * *$ \\
\hline $\begin{array}{l}\text { Organizational } \\
\text { Performance }\end{array}$ & $<---$ Education & 0.420 & 0.073 & 5.795 & $* * *$ \\
\hline $\begin{array}{l}\text { Organizational } \\
\text { Performance }\end{array}$ & $<--$ Trust & 0.443 & 0.068 & 6.525 & $* * *$ \\
\hline
\end{tabular}

Source: Primary Data, 2019 (processed)

The effect of communication on the performance of member is obtained by the estimated critical ratio (CR) parameter value of 9.733 and with a probability of 0.000 . Thus the CR value is greater than the table value that is equal to 1.97 and the probability is smaller than 0.05 .

The effect of education on the performance of the member obtains the estimated value of the critical ratio (CR) parameter of 7.951 which is greater than the table of 1.97 and the probability of less than 0.05 . Thus it explains that the education owned by members of the PidiePolantas has an influence on improving the performance of members.

The effect of trust on the member performance obtains the estimated critical ratio (CR) parameter value of 7.367 which is greater than the value of 1.97 and a probability smaller than 0.05. Thus it figures that the trust given to members of the police will have an effect on improving the performance of members of the PidiePolantas.

The effect of the member performance on organizational performance of the PidiePolantas obtains the estimated critical ratio (CR) parameter value of 8.235 which was greater than the ttable value of 1.97 and the probability of being smaller than 0.05 . Thus it illustrates that the performance of members effects the performance of the PidiePolantas.

The effect of communication on organizational performance of the PidiePolantas obtains the estimated critical ratio (CR) parameter value of 8.763 which is greater than the t-table value of 1.97 and the probability is smaller than 0.05 . Thus it can be concluded that communication that is happened in the PidiePolantas organization affects its organizational performance.

The effect of education on organizational performance of the Pidie Police Traffic Police obtains the estimated critical ratio (CR) parameter value of 5.795 which is greater than the ttable value of 1.97 and the probability is smaller than 0.05 . Thus it reveals that education has an influence on improving the performance of the PidiePolantas. 


\section{International Journal of Business Management and Economic Review}

Vol. 3, No. 01; 2020

ISSN: 2581-4664

The effect of trust onorganizational performance of the PidiePolantas obtains the estimated critical ratio (CR) parameter value of 6.525 which is greater than the t-table value of 1.97 and the probability is smaller than 0.05 . Thus it explains that the trust given or received by members of the PidiePolantas has an influence on improving its organizational performance.

\section{Indirect Effect}

The direct effect of communication on member performance is 0.776 . While the effect of communication on the performance of the PidiePolantasthrough member performance is 0.657. This means that if you want to improve the performance of the PidiePolantas, it will be better if the leadership directly improves communication, especially related to the communication made by the leadership and also other elements in a coordination to improve its performance.

The direct effect of the education on member performance is 0.741 . While the effect of education on the performance of the PidiePolantasthrough member performance is 0.354 . This means that if you want to improve the performance of the PidiePolantas, it will be better if the leadership can provide opportunities to attend education to members who are deemed to have the ability to increase knowledge and increase insight of the members.

The direct effect of trust on member performance is 0.242 . While the effect of trust on the performance of the PidiePolantasthrough member performance is 0.374 . This means that if you want to improve the performance of the PidiePolantas, it will be better if the leadership can increase the trust given especially by increasing trust and assigning tasks and functions in accordance with the capabilities of the members.

From Discussion above, it can be seen that all the verified hypotheses tested fulfill the requirements to be accepted, so it can be concluded that hypotheses both diret and indirect effect of $1,2,3,4,5,6,7,8,9$ and 10 are acceptable. In other words, the independent and intervening variables have an influence to increase the dependent variable.

\section{CONCLUSION}

The research result shows that communication effects member performance, Education effects member performance, Trust effects member performance, Member performance effects organizational performance, Communication effects organizational performance, Education effects organizational performance, Trust effects organizational performance, Communication effects organizational performance through member performance, Education effects organizational performance through member performance, and Trust effects organizational performance through member performance. This research model can be a reference for academic and practical lessons that update the previous theories especially in the causalities. The new findings lies in its new object, that is the Pidie Polantas, and the combination of causality theories. The limitation resides in the amount of variables, and only use one object.

Some of implications is formulated. Based on a communication perspective, what needs to be considered is the members must be able to communicate better with the public regarding traffic regulations. Each member also must get education continously in accordance with the needs in carrying out tasks in the traffic unit, and theyneed to strive more to become people who have honest, sincere integrity, so it will increase the trust both among themselves and with the community related. 
Vol. 3, No. 01; 2020

ISSN: 2581-4664

\section{REFERENCES}

Atmojo, M. (2012) 'The Influence of Transformational Leadership on Job Satisfaction, Organizational Commitment, and Employee Performance', International Research Journal of Business Studies, 5(2), pp. 113-128. doi: DOI: 10.21632/irjbs.5.2.113-128.

Atmosudirdjo, S. P. (1982) Administrasi dan management umum. Jakarta: Ghalia Indonesia. Bernardin, H. J. (2009) Human Resource Management. 5th edn. New York: McGraw-Hill. Effendy, O. U. (2013) Ilmu Komunikasi Teori Dan Praktek. Bandung: Remaja Rosdakarya.

F. Hair Jr, J. et al. (2014) 'Partial least squares structural equation modeling (PLS-SEM) An emerging tool in business research', European Business Review. Emerald Group Publishing Limited, 26(2), pp. 106-121.

Fahmi, M. L. Al (2013) Analisis Pengaruh Dukungan Perusahaan Dan Kepemimpinan Terhadap Kinerja Karyawan Serta Dampaknya Pada Kinerja Pt. Bank Syariah Mandiri Cabang Langsa Aceh. Syiah Kuala University.

Ghani, Z. A. (2001) Islam, komunikasi dan teknologi maklumat. Malaysia: Utusan Publications.

Handoko, H. (2008) Manajemen personalia dan Sumberdaya Manusia. 2nd edn. Yogyakarta: BPFE.

Hariandja, M. T. E. and Hardiwati, Y. (2002) Manajemen sumber daya manusia: pengadaan, pengembangan, pengkompensasian, dan peningkatan produktivitas pegawai. Jakarta: Gramedia Widiasarana Indonesia (Grasindo).

Hasibuan, M. S. P. (2011) Manajemen Dasar, Pengertian dan Masalah. Revisi. Jakarta: Bumi Aksara.

Jamaluddin (2014) Pengaruh Pendidikan Dan Pelatihan Terhadap Kinerja Pegawai Balai Budidaya Air Payau Ujung Rnbatee Aceh Besar. Syiah Kuala.

Lussier, R. (2016) Human Relations in Organizations: Applications and Skill Building (Irwin Management). 10th edn. New York: McGraw-Hill.

Margiati, L. (1999) 'tres Kerja:Latarbetakang Penyebab dan Alternatif Pemecahannya', Masyarakat, Kebudayaan dan Politik, Thn XII(3), pp. 71-80.

Mooney, J. D. and Reiley, A. C. (1931) Onward Industry! First. New York: Harper and Bros.

Robbins, S. P. and Judge, T. A. (2012) Organizational Behavior. 15th edn. Edited by S. Yagan. San Diego: Pearson.

Simamora, H. (2004) Manajemen Sumber Daya Manusia. Edisi III. Jakarta: STIE YKPN.

Sobandi, B. et al. (2006) Desentralisasi dan tuntutan penataan kelembagaan daerah. Bandung: Humaniora.

Sujardi (2009) Pengembangan Kinerja Pelayanan Publik. Bandung: Refika Aditama.

Sulaiman (2013) Pengaruh Gaya Kepemimpinan Dan Gaya Komunikasi Terhadap Kinerja Pegawai Serta Dampaknya Pada Kinerja Sekretariat Daerah Kabupaten Pidie Jaya. Syiah Kuala University.

Widjaja, H. A. W. (2003) Otonomi desa merupakan otonomi yang asli, bulat, dan utuh. Jawa Barat: Raja Grafindo Persada.

Zainal, V. R. (2015) Manajemen Sumber Daya Manusia Untuk Perusahaan: Dari Teori ke Praktik. Edisi Keti, Jakarta: PT. Raja Grafindo Persadi. Edisi Keti. Depok: PT. Rajagrafindo Persada. 